7. Ustawa o działalnośći pozytku publicznego i o wolontariacie. Dziennik Ustaw Rzeczypospolitej Polskiej. 2003. № 96. P. 873.

8. Ustawa Prawo o stowarzyszeniach z dnia 7 kwietnia 1989 roku (z pyźn. zmianami). Dziennik Ustaw Rzeczypospolitej Polskiej. 1989. Nr 20. Poz. 104.

\title{
DOI https://doi.org/10.30525/978-9934-26-120-6-7
}

\section{ПОСТАВКИ ОЗБРОЄННЯ РАДЯНСЬКИМ СОЮЗОМ ДО АФГАНІСТАНУ В 1989-1991 РР.}

\author{
Ковальков О. Л. \\ кандидат історичних наук, \\ доиент кафедри всесвітньої історії \\ Центральноукраӥнський державний педагогічний університет \\ імені Володимира Винниченка \\ м. Кропивницький, Украӥна
}

15 лютого 1989 p. радянські війська залишили Афганістан. Але i після цього СРСР підтримував марксистський режим в громадянській війні проти опозиції. Одним із засобів цього були поставки зброї і військової техніки.

Під час і після виведення радянських військ президент М. Наджибулла закликав переглянути графік виконання Женевських угод, переконував у необхідності залишення частини радянських військ або завдання авіаційних ударів по позиціях моджахедів 3 теритоpiï СРСР. Ці заклики підтримали міністр закордонних справ СРСР Е. А. Шеварнадзе і Голова КДБ В. О. Крючков. Натомість М. С. Горбачов і решта членів Політбюро ЦК КПРС були проти цього [9, с. 122]. Проте відмовивши М. Наджибуллі у військовій підтримці, в Кремлі вирішили збільшити поставки зброї і військової техніки до Афганістану. СРСР надавав Афганістану озброєння за 25\% вартості в кредит під $2 \%$ річних.

3 метою посилення військових позицій кабульського режиму 25 січня 1989 р. Політбюро ЦК КПРС схвалило пропозиції Ради міністрів СРСР від 1 січня того ж року «про безоплатне передавання військової і спеціальної техніки, боєприпасів та іншого майна військового і цивільного призначення» афганській армії [1, с. 199]. Це були 900 танків, БМП і БТР, 270 гармат, 50 тис. т боєприпасів, 32 тис. т 
продовольства, 1 тис. т медикаментів, 184 військові містечка [12, с. 34] на загальну суму майже 700 млн. руб. [6, С. 312].

Надалі рішення про військові поставки до Афганістану були регулярними. 7 березня 1989 р. Політбюро схвалило безоплатну поставку в 1989 р. до Афганістану артилерійських боєприпасів і авіаційних бомб [1, с. 201]. 12 березня було вирішено передати Афганістану 24 літаки Су-22 і МіГ-21, 8 пускових установок (ПУ) ракет P-17 і 25 фугасних бойових частин до них, 200 ракет Р-17 в неядерному оснащенні і 200 фугасних бойових частин до них, а також надати танки й іншу бойову техніку [2].

1 i 10 квітня Політбюро розглядало питання «Про надання додаткової військової допомоги Республіці Афганістан у квітні-травні 1989 р.» [1, с. 202], проте конкретні ії статті встановити не вдалося. 19 травня 1989 р. ухвалили надати в травні-червні 12 ракет-носіїв Р-300 і бойових частин до них; 1,5 тис. 200-мм реактивних снарядів до реактивної системи залпового вогню (РСЗВ) «Ураган»; по 1 тис. 100 мм. і 115 мм танкових снарядів; 100 комплектів пускових механізмів і 500 ракет до протитанкового комплексу «Метис»; 1 тис. комплектів парашутно-десантних систем ПДС-500, а також переносний зенітно-ракетний комплекс «Стріла-2» з радянськими фахівцями [3].

10 липня 1989 р. ЦК КПРС ухвалив надати Афганістану дві бойові і дві резервні ПУ тактичного ракетного комплексу (ТРК) 9К52 («ЛунаМ») і 300 ракет до них [10]. 22 липня 1989 р. Політбюро ухвалило до кінця року додатково (до вже поставленого на 1,5 млрд. руб.) надати Афганістану зброї на 2,6 млрд. руб. Йшлося про 2 ПУ ТРК Р-17-Э і 350 ракет до них, 30 танків, 4 БТР, 16 РСЗВ «Ураган», 30 мінометів, 615 гранатометів, 500 вогнеметів, 15 зенітних установок, 11 тис. одиниць стрілецької зброї, 24 літаки та ін. [4].

Особлива увага приділялася поставкам боєкомплектів до ТРК. Після виведення радянських військ саме наявність цієї зброї забезпечувала перевагу урядової афганської армії. Як звітував Генеральний штаб, СРСР постійно забезпечував 6-8 добову потребу армії Афганістану в таких ракетах [8].

24-30 липня 1989 р. у Кабулі працювала група офіцерів і генералів міністерства оборони СРСР. За підсумками оцінки стану оборони країни було ухвалено додатково надати 4 ПУ ракетного комплексу P-17-Э, 1 тис. вантажних автомобілів, 20 командирських бойових розвідувальних машин БРМ-1К, 200 керованих ракет для протитанкових ракетних комплексів «Штурм» [5]. 3 серпня 1989 р. Е. А. Шеварнадзе і Д. Т. Язов звернулися до ЦК КПРС 3 обгрунтуванням додаткової військової допомоги Кабулу. Політбюро ЦК 
КПРС зобов'язало уряд розробити і подати відповідні пропозиції [1, с. 207]. 5 жовтня 1989 р. в черговій записці до ЦК КПРС йшлося про необхідність додаткових поставок до Афганістану авіаційної техніки й автомобілів [1, с. 211].

На початку листопада 1989 p. М. Наджибулла писав М. С. Горбачову, що лише авіаційні, артилерійські і ракетні удари дозволяли стримувати наступи моджахедів. Він закликав збільшити щоденні поставки ракет Р-300 до 10-12 штук, відновити поставки ракет до «Луни-М» і надати термінову допомогу у відновленні авіапарку, який втратив 70 літаків і вертольотів менш ніж за рік. Окрім сприяння в ï ремонті, він просив вертольоти Мi-35 і літаки МіГ-29 і Су-27 [13]. М. С. Горбачов відповів, що до кінця року Афганістан отримає 500 ракет до Р-300, 100 ракет до «Луна-М» і літаки МіГ-29. Вертольоти Мi-35 мали надійти в першому кварталі 1990 р. [14].

В кінці 1989 р. СРСР погодив поставки до Афганістану значного арсеналу на загалом майже 1,5 млрд. руб. Це були 150 ракет до ТРК Р17, дві ПУ ТРК «Луна-М», 380 танків, 865 БМП і БТР, 195 гармат і мінометів, 680 зенітних гармат і установок, 1 тис. реактивних вогнеметів, близько 96 тис. одиниць стрілецької зброї, 54 літаки, 6 гелікоптерів, понад 1500 парашутно-вантажних систем багаторазового використання, боєприпаси, інженерна техніка, засоби зв'язку [11, с. 175]. 21 березня 1990 р. заступник Міністра оборони генерал М. А. Мойсеєв надіслав до ЦК КПРС листа, в якому обгрунтовував необхідність поставки до Афганістану в 1990 р. військової техніки і засобів зв'язку на загальну суму 1,8 млрд. руб. [1, с. 220]. В документі 3-поміж іншого згадані 28 літаків різних типів і шість вертольотів Мi-35. Останній задокументований факт передачі Афганістану радянської військової техніки датовано вереснем 1991 р. Тоді афганські ВПС поповнили 15 фронтових бомбардувальників Су-24МК [7, с. 42].

Таким чином, СРСР і після виведення своїх військ лишався учасником конфлікту в Афганістані. Поставки сучасної і високотехнологічної зброї та військової техніки дозволили режиму М. Наджибулли не лише успішно протистояти, але й пережити свого покровителя. Лише після припинення радянської допомоги в кінці 1991 р. режим «Ватан» було повалено навесні наступного року.

\section{Література:}

1. Архивы Кремля и Старой площади. Документы по «делу КПСС» / Сост. И. И. Кудрявцев. Новосибирск: Сибирский хронограф, 1995. $326 \mathrm{c}$. 
2. Выписка из протокола №149 заседания Политбюро ЦК КПСС от 12 марта 1989 года. О дополнительных мерах по оказанию срочной помощи Республике Афганистан. Архив Национальной безопасности Университета Дж. Вашингтона. URL: https://nsarchive2.gwu.edu//rus/ text_files/Afganistan/1989.03.12\%20CC\%20on\%20Afgh.pdf

(дата звернення: 07.07.2021).

3. Выписка из протокола №159 заседания Политбюро ЦК КПСС от 19 мая 1989 года. Об оказании дополнительной помощи Республике Афганистан. Архив Национальной безопасности Университета Дж. Вашингтона. URL: https://nsarchive2.gwu.edu//rus/text_files/ Afganistan/1989.05.19\%20CC \%20on\%20Afgh.pdf_(дата звернення: 07.07.2021).

4. Выписка из протокола №163 заседания Политбюро ЦК КПСС «О дополнительной поставке специмущества Республике Афганистан». 22 июля 1989 г. Архив Национальной безопасности Университета Дж. Вашингтона. URL: https://nsarchive2.gwu.edu//rus/text_files/ Afganistan/1989.10.22\%20CC\%20on\%20Afgh.pdf (дата звернення: 07.07.2021).

5. Выписка из протокола №164 заседания Политбюро ЦК КПСС «Об оказании дополнительной военной помощи Республике Афганистан». 5 августа 1989 г. Архив Национальной безопасности Университета Дж. Вашингтона. URL: https://nsarchive2.gwu.edu// rus/text_files/Afganis $\tan / 1989.08 .05 \% 20 \mathrm{CC} \% 20 \mathrm{on} \% 20 \mathrm{Afgh} . p d f \quad$ (дата звернення: 07.07.2021).

6. Громов Б. В. Ограниченный контингент. М.: Прогресс, 1994. $352 \mathrm{c}$.

7. Жирохов М. Когда ушли шурави. Авиация в Афганистане: 1989-2001 гг. Авиамастер. 2003. № 6. С. 42-49.

8. Записка Генерального Штаба в ЦК т. Зайкову №312/1/0297 от 31.07.89. «Об обеспечении Афганистана военной техникой». Советский архив, собран Владимиром Буковским. URL: http://www.bukovsky-archives. net/pdfs/afgh/ arm89-2.pdf_(дата звернення: 07.07.2021).

9. Ковальков О. Л. Позиція радянського керівництва щодо «афганського питання» напередодні та після виведення радянських військ із Афганістану (1985-1991рр.) Вчені записки Таврійського національного університету імені В. І. Вернадського. Історичні науки. Київ, 2021. №2. С. 118-125.

10. Постановление ЦК КПСС о поставке Республике Афганистан тактического ракетного комплекса 9К52 («Луна-М»). - 10 июля 1989 г. - Архив Национальной безопасности Университета 
Дж. Вашингтона. URL: https://nsarchive2.gwu.edu//rus/text_files/ Afganistan/1989.07.10\%20CC \%20on\%20Afgh.pdf__дата звернення: 07.07.2021).

11. Слинкин М. Ф. Афганистан. Страницы истории (80-90-е гг. XX века) Культура народов Причерноморья. Симферополь, 2003. № 41.279 c.

12. Тимин Л. В. После вывода войск... Львов: Добра справа, 2009. $260 \mathrm{c}$.

13. Letter From Afghan President Najibullah to CSPU General Secretary Michail Gorbachov (Excerpt). November 5, 1989. Wilson Center. Digital Archive. URL: https://digitalarchive.wilsoncenter.org/document/ 117286 (дата звернення: 07.07.2021).

14. Letter From CSPU General Secretary Michail Gorbachov to Afghan Government. December 11, 1989 Wilson Center. Digital Archive. URL: https://digitalarchive.wilsoncenter.org/document/117289____ата звернення: 07.07.2021).

DOI https://doi.org/10.30525/978-9934-26-120-6-8

СТИЛІСТИЧНІ ОСОБЛИВОСТІ ТВОРІНЬ ЗОДЧОГО Ю. М. ДМИТРЕНКА (У КОНТЕКСТІ ЄВРОПЕЙСЬКИХ ВПЛИВІВ)

\author{
Письмак Ю. О. \\ старший викладач кафедри архітектурних конструкиій \\ Одеська державна академія будівництва та архітектури \\ м. Одеса, Україна
}

Серед творінь зодчого Юрія Дмитренка, перш за все привернула увагу велична будівля, розташована у середмісті Одеси: збудований на початку XX століття (1905р.) 4-поверховий житловий (прибутковий) будинок, розташований за адресою: м. Одеса, вул. Грецька, 25, ріг вул. Єкатерининської, 25. Розташування будівлі - наріжне. Будівля складної конфігурації у плані, з двома сполученими дворами й проїздом, формує квартал. У забудові кварталу будинок виділяється і завдяки своїй висоті, оскільки має контрастний вигляд на тлі сусідніх малоповерхових будівель. Автор будівлі - видатний український зодчий Ю. М. Дмитренко (1858-1918) створив ії̈ у період своєї творчої зрілості. Його талант у поєднанні 3 великими фінансовими можливостями замовника - багатого підприємця грецького походження 32 